DOI https://doi.org/10.30525/978-9934-26-110-7-19

\title{
ОБРАЗ РОКСОЛАНИ У РОМАНІ М. ЛАЗОРСЬКОГО «СТЕПОВА КВІТКА»
}

\author{
Теркун В. A. \\ магістрантка групи У-51 \\ Полтавський національний педагогічний університет \\ імені В. Г. Короленка \\ Радько Г. I. \\ кандидат філологічних наук, дочент, \\ доцентка кафедри української літератури \\ Полтавський національний педагогічний університет \\ імені В. Г. Короленка \\ м. Полтава, Украӥна
}

Поряд 3 письменниками материкової України своєрідні компенсаційні функції щодо української культури виконували й українські письменники в еміграції. На жаль, до сьогоднішнього дня досягнення багатьох представників зарубіжної української інтелігенції залишаються ще недостатньо дослідженими та відомими широкому загалу в Україні. Серед них і твори Миколи Лазорського (1890-1970). Україна в історичному романі М. Лазорського представлена в образах Роксолани («степової квітки») - Настусі Висовської, двох великих магнатських родів - Вишневецьких і Глинських, що фактично володіли Полтавщиною у середині XVI ст., а також описами степу, топонімами Полтавщини: Санджар, Полтави, Перещепино, Лубен; Липової долини, Чернігова, Києва, Запорожжя; історичною дійсністію XVI-XVIII ст., зображальним конкретним образом України - Степової України. Образ степу постає в описах і рецепціях персонажів часто: «Панна Настуня теж спокійно оглядала степ: вона нічого не боялась, бо ж тут був пан Ярема! ...

- Як тут гарно! Який пишний краєвид аж до обрію! - казала Настуся, виходячи з берлини й оглядаючи гай» [2, с. 18].

М. Лазорський подав свою, цілком оригінальну художню інтерпретацію образу Роксолани, ввівши його у вир українського козацького життя середини XVI ст. Роксолана Миколи Лазорського - це не традиційна попівна Настя Лісовська 3-під Рогатина, а козачка із Санджар на Полтавщині, дочка сотника Дороша Висовського. Виховувалася вона в чернігівському Слецькому монастирі, дома жила в 
козацькому середовищі, мала нареченого Ярему Сангушка. Влітку на свято Івана Купала на Санджари напали ординці, убили сотника, полонили Настю та інших сільських дівчат. Із Криму Настю відправили до Стамбула і подарували в султанський гарем, де іiі помітив султан Сулейман [див.: 2].

Осмислюючи образ Насті, проф. О. Мишанич пише «Письменник не ідеалізує Роксолану, показує весь трагізм іiі долі. Щоб вижити й утвердити себе у становищі першої дружини султана і матері спадкоємця престолу, Роксолана виявляє сильний характер, неабияку енергію, рішучість і природний розум, залишаючись водночас лише слабкою жінкою, невільницею змушеною коритися силі, жорстокості й підступності султанського двору» [3, с. V].

Образ Роксолани - не новий у літературі, до нього зверталися, як українські письменники (Л. Старицька-Черняхівська, Д. Січинський, О. Назарук, Г. Якимович, С. Плачинда), так і іноземні (С. Твардовський, Й. Тралоу, М. Вальтарі). Найновішою версією цієї теми $є$ роман «Роксолана» П. Загребельного (1980). Порівнювати роман М. Лазорського «Степова квітка» 3 іншими творами про Роксолану не будемо, оскільки це потребує окремої теми.

М. Лазорський створив образ українки-патріотки, яка потрапивши в екстремальні обставини змогла зберегти свою людську та жіночу гідність, через усе своє непросте життя пронесла любов до рідної Батьківщини. «Про Україну та українців побутує багато міфів i стереотипів як національних, так й іноземних, які формувалися протягом тривалого періоду становлення держави, саме тому їх важко викорінити. Роксолана належить до категорії образів, які перетворилися на символи, відомі всьому світові, уособлюючи в собі власний національний міф: розум і жіночність української жінки» [1, с. 6]. «Тільки мавзолей Роксолани все стоїть на сторожі самотою та ще золоті літери на ньому яскраво промовляють про чини тої, яка все своє життя дбала про справедливість... Нікого тут немає, нікого й ніколи, лише самотня тополя високо піднеслася вгору й тихо шелестить зеленим листячком, хилячись вітями до могили» [2, с. 289].

Історія життя Роксолани тісно переплітається з історією козацтва, 3 історією України. Драма однієї дівчини Насті розгортається на тлі драми всього українського народу, коли його 3 усіх боків починають притискати: «з півдня - турецько-татарські орди, з північного заходу польсько-литовська держава, а на півночі - спокою не давала хижа загарбницька політика московських самодержців. Український народ, який ледве піднявся після Батиєвої навали, опиняється між трьома 
вогнями. Його зраджує еліта, одна частина якої переходить на службу Речі Посполитої, а друга все частіше поглядає на Москву, шукаючи там для себе вигоди. Саме в цей час на Низу Дніпра починає формуватися нова політична і військова сила - українське козацтво, якому судилося у XVI-XVIII ст. захищати Україну, боротися за ії честь, волю i державність 3 турецько-татарськими вторгненнями, польсько-шляхетським наступом і московською імперською жадібністю» [4, с. 201].

Письменник художньо відтворив ту напружену обстановку в Україні середини й другої половини XVI ст., яка привела до вибуху селянськокозацьких повстань Косинського і Наливайка, готувала грунт для народно-визвольної війни під керівництвом Богдана Хмельницького.

У романі правдиво відтворено розстановку політичних сил в Україні середини XVI ст. На прикладі двох великих магнатських українських родів Вишневецьких і Глинських бачимо, як ці роди роздвоїлися i в ім'я власної користі поступилися національними і релігійними інтересами свого народу. Однак у пошуках вигоди рід Глинських загинув у московських казематах, відігравши певну роль у царських міжусобицях. Представник роду Вишневецьких - Дмитро стає засновником Запорозької Січі, гуртує козацтво для відсічі ординцям з півдня. Однак потрапивши в полон, він гине від руки ката на майдані Стамбула, ставши прототипом героя відомої історичної пісні про Байду. Інші представники цього роду, зрадивши інтереси України, стали вірними слугами польського короля, породивши таких лютих ворогів українського народу i його визвольних змагань, як Ярема Вишневецький.

Лише інколи вдаючись до невеликих історичних екскурсів, М. Лазорський художньо відтворив ту напружену обстановку в Україні середини і другої половини XVI ст., що привела до вибуху селянськокозацьких повстань Косинського і Наливайка, готувала грунт для народно-визвольної війни під керівництвом Богдана Хмельницького. «Кращі його сини тікали на Січ і там готувалися до нових бойових виправ, гартували міць і волю, оберігали свою віру, національну свідомість і честь» [3, с. VI]. «Січ була у всіх на вустах, говорили про неї, як про якесь иарство волі і права, про неї співали кобзарі, складали пісні... Ходили по всій Украӥні дивні чутки, по всіх закутках розповідали про якогось велетня-козака, що ось-ось вчинить ворогу смертельну бурю й зробить лад $і$ мир скрізь в Україні. По селах, містах козацтво жадібно вдивлялося в обрій, шукало там того казкового лицаря, щцо вже, кажуть, летить на вогненному коні на захист-порятунок невільників.

Всі ждали чуда. 
На всю Польщу густою пеленою падала грізна тінь великого гетьмана Богдана Хмельницького» [2, с. 313].

Підсумовуючи, можна відзначити, що образ Роксолани - це своєрідний художній феномен М. Лазорського. Роман «Степова квітка» посідає чільне місце 3-поміж інших історичних романів письменника та українського історичного роману загалом у розвитку української літератури XX ст. Дослідження історії України через відомий образ українки в романі «Степова квітка» Миколи Лазорського дає можливість закріпити теоретичні знання на практиці про засоби образотворення та його види, розширює і збагачує світогляд читача і молодого дослідника, знання про минуле, погляди на історію та майбутнє своєї країни, на міру художньої та історичної правди в історичних романах.

\section{Література:}

1. Герасименко Ю. А. Рецепція української історії в західноєвропейській прозі кінця XX - початку XXI століття. [Текст] : дис. на здоб. наук. ступ. канд. філол. наук : 10.01 .05 - порівняльне літературознавство. Бердянський держ. пед. ун-т. Бердянськ, 2019. 259 с.

2. Лазорський М. Степова квітка. Мюнхен: Видавництво Дніпрова хвиля, 1965. $365 \mathrm{c}$.

3. Мишанич О. Історичні романи Миколи Лазорського // Лазорський М. Степова квітка. Мюнхен: Видавництво Дніпрова хвиля, 1965. C. III-VI.

4. Скорина Л. Література та літературознавство української діаспори. Курс лекцій. 2-ге, доповн. Черкаси : Брама-Україна. 2005. $384 \mathrm{c}$. 